\title{
Transfer of nurse education to universities under a model of person- centred care: A consequence of changes in Spanish society during the democratic transition
}

\section{Olga Rodrigo}

School of Nursing, Campus Docent Sant Joan de Déu, University of Barcelona Esplugues de Llobregat, Barcelona, Spain

\section{Jordi Caïs}

Department of Sociology and Organizational Analysis, University of Barcelona Barcelona, Spain

\section{Cristina Monforte-Royo}

Nursing Department, School of Medicine and Health Science. Universitat Internacional de Catalunya, Sant Cugat del Vallés, Barcelona, Spain

\begin{abstract}
Background. In Spain the transfer of nurse education to universities was accompanied by a shift towards a model of person-centred care.

Aim. To explore whether the change in nurses' professional profile (from physician assistant to providers of person-centred care) was a response to changing needs in Spanish society.

Design. Qualitative study.

Methods. Theoretical sampling and in-depth interviews using an inductive analytical approach.

Results. Four categories described the nursing profession in Spain prior to the introduction of university training: the era of medical assistants; technologisation of hospitals; personal care of the patient based on Christian values; professional socialisation differentiated by gender. Further analysis showed that these categories could be subsumed under a broader core category: the transfer of nurse education to universities as part of Spain's transition to democracy.

Conclusion. The transfer of nurse education to universities was one of several changes occurring in Spanish society during the country's transition to democratic government. The redefined public health system required a highly skilled workforce, with improved employment rights being given to female health professionals, notably nurses.
\end{abstract}

Keywords: Feminism; Inductive study; Nurses' role; Nursing History; Politics; Qualitative research; Spain; University. 


\section{INTRODUCTION}

Although the origins of modern nursing can be traced back to the work of Florence Nightingale (1820-1910) (Bullough \& Bullough, 1981), the model of person-centred care (Bartol \& Ford, 2015) did not begin to develop formally until the 1950s in the USA (Bullough \& Bullough, 1981; Shaw, 1993). In Spain, the same period saw the implementation of a new state registration scheme for nurses (see the Official Gazette of the Spanish government: Boletín Oficial del Estado, 1953), although in contrast to the direction of change in the USA this new qualification reinforced the nurse's role as medical assistant (Domínguez-Alcón et al., 1983, p.103). However, when, in 1977, nurse education in Spain was transferred to universities (Boletín Oficial del Estado, 1977a)this was accompanied by a shift towards a model of personcentred practice, similar to that already established in the Anglo-American context. What is unclear is the extent to which this shift reflected the natural evolution of the discipline towards a model of person-centred care.

\section{BACKGROUND}

Nursing as a profession in Spain began to be officially recognised in 1857, when the government of the day passed a law (Boletín Oficial del Estado, 1857) regarding the training of three categories of nurse: practitioner, matron and nurse. Practitioners (men) and matrons (women) worked as physician assistants in rural and non-hospital settings. By contrast, the role of nurses (women), who were hospital-based and generally members of religious orders, was to feed and wash patients under the supervision of physicians(Ortega,1996, p. 291).

The reorganization of the Spanish health system in the 1950s led to the building of larger hospitals and the introduction of new technology, and this required a greater number of trained staff(German, 2013, p. 220; Santo-Tomás, 2000, p. 93). In order to address the need for more nurses with adequate training (Sellán,2010, p. 220) a new state registration scheme was introduced, one which unified the existing categories of nurse into a single qualification known as ATS (Technical Healthcare Assistant) (Boletín Oficial del Estado, 1955). This qualification required nurses to achieve a higher academic and skills level, with sole responsibility for the content of nurse training being given to faculties of medicine. Nurses could also extend their skills through specialist training once the basic ATS qualification had been obtained (García\& Martínez, 2001, p. 150). However, the role assigned to this new category of nurse continued to be that of physician assistant (Hernández\& Moral, 1995, p. 151).

Subsequently, at the beginning of the 1970s, several groups of Spanish nurses began to campaign for nursing to become a more scientific and university-based discipline, and for there to be a shift in the nurse's role towards person-centred practice of the kind found in the USA and Canada (García \& Martínez, 2001, p. 185). After much negotiation within the profession (Germán, 2013, p. 89) the ATS qualification was officially replaced in 1977 by a university Diploma in Nursing (Boletín Oficial del Estado, 1977b), whose syllabus was geared towards training nurses in the model of person-centred care (German, 2013, p. 196; Santo-Tomás, 2000, p. 105) that had been borrowed from the Anglo-American context. This led to a process of what Neiterman and Bourgeault (2015) refer to as professional socialization, since not only did nurses have to acquire the knowledge and skills required by this new role, but a new academic culture had to be created in Spain, one that would enable this new professional identity to develop. 
According to Cortina (2000) a profession can be conceptualised as a cooperative social activity whose purpose is to offer society a specific service without which society would not survive. In the context of the nursing profession in Spain the question is to what extent the transfer of nurse education to universities and the shift in role from physician assistant to a model of person-centred practice reflected the natural evolution of the discipline in response to the changing needs of Spanish society.

\section{METHODS}

The aims are 1) to explore, the reasons behind the shift in nurses' profile in Spain, from the traditional role of physician assistant to an Anglo-American style model of person-centred care linked to a university qualification, and 2) to determine the extent to which this shift was a response to the changing needs of Spanish society.

This is a qualitative study with an inductive analytical approach based on the formulation of an initial hypothesis and the subsequent selection of extreme cases (Borobia, 2004). Sampling was theoretical, with data analysis guiding the subsequent selection of new participants (Smelter \& Baltes, 2001). The characteristics and number of participants to be recruited were established according to the criteria of sufficiency (Seidman, 2013) and theoretical saturation (Strauss \& Corbin, 2002). The main inclusion criterion was that participants should have been employed as nurses with the ATS qualification at the point when nurse education was transferred to universities.

Data were gathered through in-depth interviews designed in accordance with the recommendations of Seidman (2013), that is, the sequential exploration of three topics (Table 1) in order to help explore the participant's experience. Participants were recruited through the university nursing schools and professional societies with which the three authors had contact. The initial contact with potential participants was via email and involved providing them with information about the study and requesting their participation. The date and time for a face-toface interview was then agreed, in a place of the participant's choosing. Written informed consent was obtained at the beginning of each interview, prior to any kind of data collection. All the interviews were recorded and transcribed using the F4 software.

The study was approved by the Research Ethics Committee of the Universitat Internacional de Catalunya. All participants were informed that their responses were anonymous and that participation was voluntary. They all signed informed consent.

Data were analysed using a grounded theory approach (Strauss \& Corbin, 2002) based on theoretical sampling and the constant comparative method (Table 2)., theoretical and operational memos (Strauss \& Corbin, 2002), as well as what we shall refer to here as bibliographic memos -linking the literature to the analysis-, were generated in order to provide support for the entire analytic process (Charmaz, 2006). The analysis was performed using the software package ATLAS.ti 7.5.

Rigour was guaranteed by applying criteria of credibility, transferability, auditability and confirmability (Table 3).

\section{FINDINGS}

Interviews took place between 2013 and 2016 and lasted between 60 and 90 minutes. The final sample comprised eight nurses who earlier in their career had obtained the ATS qualification and who were employed in this capacity at the time of nurse education being transferred to universities. The first six participants were recruited with the aim of achieving maximum variability of contexts. Two extreme cases were subsequently identified. The first 
extreme case -a male nurse who was also a member of a religious order- enabled us to explore the influence of gender on the transmission of a model of care based on Christian values. The second extreme case -a male nurse who had not been exposed to Anglo-American theories and models of nursing- allowed us to examine in more detail the profile of physician assistant in Spain. As no new information was provided by the latter interviews it was concluded that theoretical saturation had been reached. Of the eight participants, six were women and two were men. Seven were working in a hospital setting, while the other was a freelance private practitioner. The participants came from four different regions of Spain: Catalonia, Andalusia, Alicante and the Balearic Islands. One of the participants had, early in her career, worked in the context of a religious nursing order.

The initial discourse analysis revealed four categories (Table 4) that described the characteristics of nursing in Spain prior to the transfer of nurse education to universities: the era of medical assistants; the technologisation of the hospital environment, leading to the disappearance of religious nursing orders; personal care of the patient based on Christian values; and professional socialisation differentiated by gender.

Application of the constant comparative method to these initial categories yielded a core category (Table 5)that explained the shift to a more academic recognition of the discipline: the transfer of nurse education to the university as part of Spain's transition to democracy following the death of Franco in 1975.

In the following sub-sections we discuss each of the four initial categories and the resulting core category, illustrating them through reference to the verbatim quotations presented in Table 4. Thus, for example, the label P2:1 in the text indicates that the point being made is supported by quotation P2:1 in Table 5.

\section{The era of medical assistants}

The role of nurses withthe ATS qualification, and especially male nurses, was that of physician assistant(P2:1) (P6:2) (Domínguez-Alcón et al., 1983, p.103) in the hospital setting, where they were principally responsible for administering medication, injections or vaccines, carrying out wound care and assisting surgeons in theatre (García \& Martínez, 2001, p. 151). Tasks such as washing and feeding patients were - in Spanish hospitals at that time - assigned to nonqualified staff referred to as 'clinical assistants' (Boletín Oficial del Estado, 1960).

Training was overseen by faculties of medicine and delivered by physicians. Students sat annual exams on the theoretical content they needed in order to fulfil the role of medical assistant (Sellan, 2010, p.191). (P1:3)

The training received by students seeking to obtain the ATS qualification was comprehensive (P1:4). Over time this led to them being highly regarded as professionals due to their practical and technical skills (Santo-Tomás, 2000, p. 101; Sellán, 2010, p. 235) and this reputation extended beyond Spanish borders. (P7:5)

However, the professional practice of these nurses in what was an increasingly technologised environment did not usually include decision making; this role was limited to physicians. Thus, nurses who obtained the ATS qualification were trained by physicians to carry out a subordinate role (P6:6) (Miró-Bonet et al., 2008), the expectation being that they would follow medical orders (P1:9) (P1:10),--not that they would achieve a high academic level (P4:7) (P6:8)

The technologisation of the hospital environment, leading to the disappearance of religious nursing orders 
The introduction of the ATS qualification in 1953 (Boletín Oficial del Estado, 1953) was the first time in Spain's history that formal training of this sort became a legal requirement for hospital-based nurses. One of the consequences of this was the progressive disappearance of religious nursing orders from the country's hospitals. Many of the women from these orders had not been formally trained as nurses (P4:1) or did not have the academic background necessary for entry to the new nurse training programme (P7:2) (Siles, 1996, p. 113).

The approach to nursing taken by the religious sisters was steeped in Christian values of austerity (P4:3), and this was something thatmany of the male nurses enrolled in the ATS training were critical of, since they saw it as the antithesis of medical professionalism. (P4:4) These male-nurses in particular, therefore, sought to create a more technical and scientific profile, one that differed as far as possible from the image of the religious nursing orders. (P4:5)

\section{Personal care of the patient based on Christian values}

Those more personal aspects of nursing care that went beyond the predominantly technical role of physician assistant were left to the discretion of individual ATS nurses(P3:1).This personal patient care became part of their working routine but because it wasn't seen as important by doctors, no written record was kept of these tasks (P3:2). As a result, these aspects of nursing care were learned through observation and imitation of professionals already working in hospitals. (P4:3)

A humanised approach to care based on Christian values continued to exist among female ATS nurses in both the academic and practical settings. This had to do with the fact that many of the hospitals and schools of nursing for female nurses were linked to religious orders (German, 2013, p. 81; Hernandez, 2006). Thus, whether as tutors in schools (P4:4) or as informal supervisors in hospitals, religious sisters continued to transmit their values to the next generation of nurses. (P6:5) However, this model of care based on Christian values was not 'patient-centred' in the sense implied by the Anglo-American model of nursing derived from the work of Florence Nightingale (Bullough \& Bullough, 1981). Indeed, the model of care applied by religious orders in Spain remained 'physician-centred', its focus being on what doctors required in order to treat the patient's illness (Domínguez-Alcón et al., 1983, p.103).

\section{Professional socialisation differentiated by gender}

Prior to 1976, the training of ATS nurses was differentiated by gender (Miró-Bonet et al.,2008)(P7:1). Men were generally trained in the faculties of medicine, which did not allow women in their classrooms (P7:2). However, there were numerous schools for women who wanted to become ATS nurses. These were attached to hospitals, many of which had formal links to religious orders (Miró-Bonet et al., 2008; German, 2013, p.81) (P7:3) (P7:4), and female trainees had to live in the corresponding nurses' home. This was not the case for men, because it was assumed that a man had to work in order to fulfil his role as family breadwinner (P7:5) (P7:6).

Differences by gender could also be seen in the training syllabus. More technical subjects, such as one entitled 'Medical and legal aspects of autopsy' were reserved for male ATS trainees, whereas the syllabus for women included subjects such as 'Homemaking' and religious education (Miró-Bonet et al., 2008), a difference that angered some female nurses (P6:7).

\section{Transfer of nurse education to universities as part of Spain's transition to democracy}


The transfer of nurse training to universities was related to the social and political changes that took place during Spain's transition to democracy following the death of Franco in 1975 (P6:1)(P5:2). In the view of Siles $(2011,451)$ this implied not only political change but also the transformation of Spanish society, which opened itself to new opportunities and different ways of meeting its needs.

Notably, this incipient democracy saw the implementation, on the back of strong public support, of a system of universal health care (P5:3), and when the Spanish Constitution was enacted in 1978, article 43 established the right of all citizens to protection of their health (Boletín Oficial del Estado, 1978). The reform of the health system led to the building of large and more technologically advanced public hospitals, and these institutions needed more medical and nursing staff (Santo-Tomas, 2000, p. 93). This meant that many more jobs were now available for existing ATS nurses (P3:4). In fact, such was the demand for qualified nurses that hospital managers visited nursing schools in order to offer students a job (P3:5). Furthermore, the fact that nurses were used to assuming responsibility in an employment context marked by long hours and limited resources, coupled with their experience in responding to a wide range of health needs, meant that they were just the kind of professional group that society needed to promote (Siles, 2011, p. 451).

However, $\mathbf{T}$ the way in which the health system was developing meant there was a need for staff whose skills went beyond the merely technical (Santo-Tomas, 2000, p. 93). At that point in time, ATS nurses were carrying out technical duties that also required a sense of responsibility and a decision-making capacity (P5:6). It became clear, therefore, that a new form of advanced training would be needed so as to enable nurses to meet the new responsibilities inherent to their role within the new health system. (P5:7)

The transition to democracy in Spain was also accompanied by growing calls for women's rights, and this had a positive impact on the nursing profession, where women were in the majority (P5:8) (P6:9). In a context of greater equality between men and women (German, 2013, p. 55), the ATS nurses (women) started to challenge the idea that they should be at the beck and call of doctors (men) (P3:10) (P3:1.). This whole generation of nurses therefore supported the common goal of raising the prestige of a predominantly female profession by linking it to a university qualification, thus giving it equal status - initially academicallywith other professions (P5:12).

\section{$\underline{\text { DISCUSSION }}$}

This study has identified a series of features that characterise the nursing profession in Spain at the time when nurse education was transferred to universities (i.e. in 1977): (a) the need within Spanish hospitals for qualified and skilled medical assistants who were able to assume responsibilities, and (b) gendered roles: female nurses providing personal care in the tradition of religious nursing orders and male nurses carrying out a purely technical role. A further aspect that has been shown to be a determining factor in this academic development concerns (c) Spain's transition to democracy and the introduction of universal health care, coupled with the social recognition of a predominantly female profession.

\section{Need within Spanish hospitals for qualified and skilled medical assistants who were able to assume responsibilities}

In 1953 the Spanish government passed legislation that subsumed the existing categories of nurse (i.e. nurse, practitioner and matron) under a new, single qualification, the ATS. This was linked to important technological developments within the country's hospital 
system that had created a demand for highly-skilled nursing professionals, who nevertheless remained subordinate to physicians (Miró-Bonet et al., 2008).

This contrasted with the direction of change introduced in the USA in 1960, whereby a greater distinction was made between the roles of physician assistant, nurse practitioner and the newly revitalized role of nurse midwife (Cawley, Cawthon, \& Hooker, 2012). This shift in the USA was the result of important cultural changes related to the civil rights and women's movement (Hooker et al., 2013). One of the consequences of the Civil Rights Act in 1964 (National Archives Foundation, 1964) was that some sort of health coverage was now available to the most disadvantaged in society(Hooker et al., 2013). In addition, the increasing technologisation of hospitals led to a rise in the number of medical specialists at the expense of primary care and general physicians. This meant, especially in rural areas, that there were too few doctors to meet the demands of the new health care system (Bartol \& Ford, 2015). It was in this context that the role of physician assistant emerged (Bartol \& Ford, 2015), a role inspired by that adopted by many American soldiers during the Vietnam war (Marzucco, Hooker, \& Ballweg, 2013). In contrast to what occurred in Spain, where the role of physician assistant was formally ascribed to ATS nurses thenursing profession in the USA, represented by the National League of Nursing, did not support such accreditation, it being argued that a delegation of medical duties was not appropriate (Cawley et al., 2012).

The extent to which the profile of US-style physician assistants has been integrated into the nursing profession varies across countries. Thus, whereas there is a clear distinction between the roles of physician assistant and nurse in the Anglo-American context, that is, in countries such as the USA (Cawley et al., 2012), Canada (Jones \& St-Pierre, 2014) and the UK (Drennan et al., 2014), the skills of a physician assistant form part of the nurse's role in European countries like Spain (Domínguez-Alcón, 1986, p. 93), Germany (Kuilman et al., 2013) and Portugal (Mendes \& Mantovani, 2009). This could be due to the way in which the nursing profession originated in these countries. In Spain, Germany and Portugal it was the medical profession which sought to create a body of technically skilled assistants (DomínguezAlcón, 1986, p. 93; Schweikardt, 2006; Mendes \& Mantovani, 2009). By contrast, in the USA, Canada and the UK, not only was it a nurse (i.e. Florence Nightingale) who initiated the process, but the aim was to train professionals capable of meeting the needs of patients (Bullough \& Bullough, 1981). Thus, there appear to be two distinct nurse identities: one resulting from a division of roles within the medical profession, and thereby predominantly technical in nature, and another that originates in an older idea of nursing, namely attending to the needs of people in hospital. The same dichotomy is discussed by Tarlier (2005) in relation to nursing epistemologies, since models of nursing in the Anglo-American context emphasise the value of care, whereas the nursing profession in Spain is founded more on the value of cure.

Another difference between ATS nurses in Spain and physician assistants in the AngloAmerican context concerns the training received: it took two years to train physician assistants in the USA, whereas three years were needed to obtain the ATS qualification in Spain, this despite the fact that the professional objective was the same, namely to equip the person to carry out routine tasks under medical supervision (Holt, 1998; Domínguez-Alcón,1986, p. 93). The longer training undergone by ATS nurses in Spain may have enabled them to acquire the technical skills required by the increasingly complex hospital environment, as well as producing nursing professionals with greater legal responsibilities and decision-making capacities, and this may have been a key factor in the decision to introduce university-based training for nurses.

Gendered roles: female nurses providing personal care in the tradition of religious nursing orders and male nurses carrying out a purely technical role 
Another feature of the profile of ATS nurses concerns the gender-based socialisation practices that remained in place until 1976, when schools of nursing finally became mixed (Boletín Oficial del Estado, 1976). On the one hand, this reflected the social status of women during Franco's dictatorship (1939-1975), whereby they were subject in law to the will of their fathers, initially, and their husbands, subsequently (German, 2007, p.53). In addition, male and female ATS nurses had clearly differentiated roles.

This differentiated socialisation was implemented through two strategies. The first was related to the different training syllabuses for male and female nurses. Training for men had a clearly technical focus, whereas the model for women emphasised the values and behaviours of submission, obedience and dependency (Miró-Bonet et al., 2008), all of which were deemed proper for women in Spanish society of the day (Ortiz, 2006). It is not clear to what extent these values remain present in what is still a predominantly female profession in Spain (Rodriguez \& Bosch, 2004), nor what effect this might have on female nurses' professional autonomy and competitiveness within the labour market.

The second socialisation strategy was related to the fact that professional training was given in clearly differentiated environments. Male nurses attended schools that were linked to faculties of medicine, but they were not required to live on site. Women, by contrast, lived in nurses' homes throughout their training, and their schools of nursing were attached to hospitals (Miró-Bonet et al, 2008), many of which were associated with religious orders. One of the consequences of this was that the professional profile of male ATS nurses did not include personal care of the patient, this being an aspect that was absent both from their training syllabus and their everyday practice. Their female counterparts, however, not only received theoretical teaching that included religious ideas, but their practical training was conducted in hospitals that retained the traditions of religious nursing orders. This meant that male ATS nurses developed an exclusively technical profile, whereas that of female nurses combined technical skills with a model of patient care that was steeped in Christian values. According to German (2013, p. 118), the small number of male nurses who worked in hospitals were assigned to laboratory services or to radiology or emergency departments, it being considered that the caring role was one for women.

\section{Transfer of nurse education to universities as part of Spain's transition to democracy}

The emergence of democratic government in Spain, which led to greater civil rights both in terms of health care and gender equality, was a key factor in the process that led to nurse education becoming the responsibility of universities. On the one hand, the development of a health system comprised of increasingly technologised hospitals offering a complex range of health care services meant there was a need for highly skilled nursing staff who were capable of assuming greater responsibilities in their working environment. Thus, the goal of the new university-based training was not only to provide the necessary academic training but also to give nurses the legal backing they needed to exert greater authority. In relation to the North American context, Watson (2006) argues that the institutional values of hospitals are driven by the economy, technology and medical science, and it can be seen that this was also the case in post-Franco Spanish society.

Another factor that influenced the transfer of nurse education to universities was the fact that men and women became equal in the eyes of Spanish law. This had important repercussions in terms of education, legislation and relationships between men and women (German, 2013, p. 53), and it meant that women, including nurses, felt that they now had the same rights as men. This likely explains why, at this key moment in Spanish history, the predominantly female nursing profession (German, 2013, p. 89; Sellán, 2010, p. 242) was so strongly in favour of nurse education becoming a university qualification, this being seen as a 
way of raising the status of the profession. In this regard, it is worth noting that as long ago as 1899 the founders of the International Council of Nursing (ICN)argued that the union of nursing leaders from across the world would contribute to greater human rights such as women's suffrage or to social reform in general(Zittel et al., 2012). The degree of professionalization of the nursing profession might therefore be regarded as an indicator of women's status in different parts of the globe.

\section{Limitations}

Two main limitations of this study need to be considered. First, the enormous range of nursing qualifications across the world makes it difficult to conduct cross-country comparisons. Second, the very nature of qualitative research implies an interaction between researcher and participants. In this regard, it has to be acknowledged that two of the authors are women and trained nurses, and their experience in both these respects may have influenced the process of data analysis and/or the creation of the theoretical narrative. In an attempt to minimise this potential bias, we held several inter-analysis meetings, both within the research team and in collaboration with an external consultant.

\section{CONCLUSION}

The transfer of nurse education to universities in Spain was a response not to calls for person-centred models of care, such as those applied in the Anglo-American context, but rather to the need of Spanish society for highly skilled professionals who were capable of decision making within the hospital setting. As such, the factors determining this change are to be found in the country's transition to democracy, a process that saw not only an increased need for skilled nurses with the capacity to assume greater responsibilities in an increasingly technologised health system, but also a change in the social status of women, who made up most of the nursing profession. In this respect, the present analysis shows how the nature of nursing is clearly influenced by particular features of the socio-historical context (Fairman \& D'Antonio, 2013), and that these shape society's view regarding the contribution that the nursing profession can make. Thus, although patient care is a core contribution of nursing, the way in which this is delivered - that is, with a greater emphasis on technical skills, as in the case of Spain, or a focus on person-centred care, as occurs in the Anglo-American context is determined by the history of the discipline in a given context and how it has sought to respond to social needs.

\section{REFERENCES}

Archives, N. (1964). The Civil Rights Act of 1964.https://www.archives.gov/education/lessons/civil-rights-act/Accessed 14.10.15

Bartol, B. T., \& Ford, L. (2015). Nurse practitioners: Enhancing healthcare for 50 years. Nurse Practitioner, 40(6), 14-16. http://doi.org/10.1097/01.NPR.0000465128.80771.ec

Boletín Oficial del Estado (1857). Ley de Instrucción Pública de 9 septiembre 1857

Boletín Oficial del Estado. (1953). Real Decreto de 4 de diciembre de 1953. 
Boletín Oficial del Estado. (1955). Orden 4 de julio 1955.

Boletín Oficial del Estado. (1960). Decreto 17 de noviembre 1960, núm. 2319/60

Boletín Oficial del Estado. (1976). Decreto 2879/76 del 30 de octubre.

Boletín Oficial del Estado. (1977a). Orden del 1 de abril de 1977, 4008-4011.

Boletín Oficial del Estado. (1977b). Real Decreto 2128/1977.

Boletín Oficial del Estado. (1978). Constitución Española del 29 de diciembre de 1978.

Borobia, R. (2004). La Hipótesis en Estudios Cualitativos. El Caso de la Inducción Analítica en una Investigación sobre Adolescencia.Revista Pilquen, Sección Ciencias Sociales, $V(6), 1-12$.

Bullough, B., \& Bullough, V. (1981).Educational Problems in a Woman's Profession.Journal of Nursing Education, 20(7), 6-17. http://doi.org/10.3928/0148-4834-19810901-03

Cawley, J., Cawthon, E., \& Hooker, R. S. (2012).Origins of the physician assistant movement in the United States.JAAPA, 25(December), 36-40.

Charmaz, K. (2006). Constructing grounded theory: a practical guide through qualitative analysis. London: Sage.

\section{Cornejo, C., \& Beseán, F. M. (2011).Desafíos en la generación de conocimiento en la investigación social cualitativa contemporánea.Forum : Qualitative Social Research, $12(1), 30$.}

Cortina, A., \& Conill, J. (2000). 10 palabras clave en ética de las profesiones. Estella: Verbo divino.

Domínguez-Alcón, C., Rodriguez, J. A., \& Miguel, J. M. de.(1983). Sociología y enfermería . Madrid: Pirámide.

Domínguez-Alcón, C. (1986). Los Cuidados y la profesión enfermera en España. Madrid: Pirámide.

Drennan, V. M., Halter, M., Brearley, S., Carneiro, W., Gabe, J., Gage, H., ... de Lusignan, S. (2014). Investigating the contribution of physician assistants to primary care in England: a mixed-methods study.Health Services and Delivery Research, 2(16), 1-136. http://doi.org/10.3310/hsdr02160

Fairman, J. \& D’Antonio, P., (2013). History counts: How history can shape our understanding of health policy. Nursing Outlook, 61(5), 346-352. http://doi.org/10.1016/j.outlook.2013.07.001

García, C., \& Martínez, M. L. (2001).Historia de la enfermería : evolución histórica del cuidado enfermero. Madrid [etc.] : Elsevier. 
German, C. (2007). Historia de la institución de la enfermería universitaria: análisis con una perspectiva de género. Retrieved from http://invenio2.unizar.es/record/4470/files/TESIS-2009-090.pdf

Germán, C. (2013). La revolución de las batas blancas: la enfermería española de 1976 a 1978. Zaragoza: Prensas de la Universidad de Zaragoza.

Hernández, J., \& Moral, P. (1995).Historia de la enfermería: un análisis histórico de los cuidados de enfermería. Madrid: McGraw-Hill/Interamericana de España.

Hernández, F. (2006).Las Hijas de la Caridad en la profesionalización de la enfermería.Cultura de los cuidados, 10(20), 39-49.

Holt, N. (1998). "Confusion's Masterpiece": The Development of the Physician Assistant Profession. Bulletin of the History of Medicine.

Hooker, R. S., Robie, S. P., Coombs, J. M., \& Cawley, J. F. (2013).The changing physician assistant profession. Journal of the American Academy of Physician Assistants, 26(9), 36-44. http://doi.org/10.1097/01.JAA.0000433914.54617.a0

Jones, I. W., \& St-Pierre, N. (2014).Physician assistants in Canada.JAAPA: Official Journal of the American Academy of Physician Assistants.

http://doi.org/10.1097/01.JAA.0000443808.97164.cb

Kuilman, L., Sundar, G., \& Cherian, K. (2013).Physician Assistant Education in Germany.The Journal of Physician Assistant Education, 23(2), 56-60.

Marzucco, J., Hooker, R. S., \& Ballweg, R. M. (2013).A history of the Alaska physician assistant, 1970-1980.JAAPA: Official Journal of the American Academy of Physician Assistants, 26(12), 45-51. http://doi.org/10.1097/01.JAA.0000437822.61279.bb

Mendes, F. R. P., \& Mantovani, M. D. F. (2009). Ensino De Enfermagem Em Portugal: Contributos Para a Sua História. Cogitare Enfermagem, 14(2), 2-7. http://doi.org/10.5380/ce.v14i2.15632

Miró-Bonet, M., Gastaldo, D., \& Gallego-Caminero, G. (2008). ¿Por qué somos como somos? Discursos y relaciones de poder en la constitución de la identidad profesional de las enfermeras en España (1956-1976).Enfermeria Clinica, 18(1), 26-34. http://doi.org/10.1016/S1130-8621(08)70690-9

Neiterman, E. \& Bourgeault, I. L.(2015). Professional integration as a process of professional resocialization: Internationally educated health professionals in Canada. Social Science and Medicine 131, 74-81. http://doi.org/10.1016/j.socscimed.2015.02.043

Ortega, G. (1996). Historia de la enfermería en España (desde la antigüedad hasta nuestros días). In Historia de la Enfermería en España: desde la antigüedad hasta nuestros días (pp. 287-323). Madrid : Síntesis. 
Ortiz, M. (2006). Mujer y dictadura franquista. Aposta: Revista de ciencias sociales, 28, 126.

Rodríguez, JA, \& Bosch, J. (2004).Enfermeras hoy: cómo somos y cómo nos gustaría ser. Conclusiones del estudio sociológico 2004. Col· legi Oficial d'Infermeria de Barcelona: Barcelona.

Santo-Tomás, M. (2000). Historia de la Enfermería. In C. Fernández Ferrín (Ed.), Enfermería Fundamental (pp. 3-129). Barcelona: Masson.

Schweikardt, C. (2006). New aspects of the German "scientific nursing" movement before World War I: Florence Nightingale's Notes on nursing disguised as part of a medical tradition. Nursing Inquiry, 13(4), 259-268. http://doi.org/10.1111/j.14401800.2006.00344.x

Seidman, I. (2013). Interviewing as qualitative research: a guide for researchers in education and the social sciences. New York: Teachers College Press. Retrieved from http://ccuc.cbuc.cat/record=b6207897 S23*cat

Sellán, M. C. (2010). La Profesión va por dentro: elementos para una historia de la enfermeria española contemporánea (2nd ed.). Madrid : FUDEN.

Shaw, M. (1993). The discipline of nursing: historical roots, current perspectives, future directions. Journal of Advanced Nursing, 18, 1651-1656. http://doi.org/10.1046/j.13652648.1993.18101651.X

Siles, J. (1996). Pasado, presente y futuro de la enfermería en España. Alicante: Consejo de Enfermería de la Comunidad Valenciana.

Smelter, N., \& Baltes, P. B. (2001).Analytic Induction.In Encyclopedia of the behavioral sciences.Elsevier.

Strauss, A. L., \& Corbin, J. (2002). Bases de la investigación cualitativa: técnicas y procedimientos para desarrollar la teoría fundamentada. Medellín: Universidad de Antioquia.

Tarlier, D. (2005).Mediating the meaning of evidence through epistemological diversity. Nursing Inquiry, 12(2), 126-134. http://doi.org/10.1111/j.1440-1800.2005.00262.x

Watson, J. (2006). Caring theory as an ethical guide to administrative and clinical practices. JONA'S Healthcare Law, Ethics and Regulation, 8(3), 87-93. http://doi.org/10.1097/00128488-200607000-00008

Zittel, B., Ceo, I. C. N., \& Benton, D. (2012). Divergence and convergence in nursing and health care among six countries participating in ICN's 2010 Global Nursing Leadership Institute. International Nursing Review, 59, 48-54. http://doi.org/DOI:10.1111/j.14667657.2011.00952.x 